\section{$\underset{\substack{\text { hommes } \\ \text { \& migrations }}}{ }$}

\section{Hommes \& migrations}

Revue française de référence sur les dynamiques

migratoires

\section{$1288 \mid 2010$}

Langues et migrations

\title{
Benda Bilili !
}

Film de Renaud Barret et Florent de La Tullaye

\section{André Videau}

\section{Q OpenEdition \\ 1 Journals}

\section{Édition électronique}

URL : http://journals.openedition.org/hommesmigrations/894

DOI : 10.4000/hommesmigrations.894

ISSN : 2262-3353

\section{Éditeur}

Musée national de l'histoire de l'immigration

\section{Édition imprimée}

Date de publication : 1 novembre 2010

Pagination : 172

ISSN : 1142-852X

\section{Référence électronique}

André Videau, « Benda Bilili ! », Hommes \& migrations [En ligne], 1288| 2010, mis en ligne le 29 mai 2013, consulté le 22 septembre 2020. URL : http://journals.openedition.org/hommesmigrations/894 ; DOI : https://doi.org/10.4000/hommesmigrations.894

Ce document a été généré automatiquement le 22 septembre 2020.

Tous droits réservés 


\title{
Benda Bilili!
}

\author{
Film de Renaud Barret et Florent de La Tullaye
}

\section{André Videau}

Dès leurs débuts cinématographiques, les documentaristes Renaud Barret et Florent de La Tullaye ont manifesté un grand intérêt pour l'Afrique et principalement pour la République démocratique du Congo et sa capitale Kinshasa, mégapole surpeuplée (qui pourrait atteindre 12 millions d'habitants en 2015), désordonnée, débordante de vie et de misère et... photogénique. Ils réaliseront notamment La Danse de Jupiter en 2004, balade musicale dans les ghettos et Victoire Terminus en 2006, documentaire sur un autre phénomène local : la boxe au féminin. Entre-temps ils ont découvert et se sont passionnés pour les pratiques musicales des "shégés", ces enfants des rues de toutes origines. Orphelins de guerre, réfugiés, migrants ruraux déscolarisés, délinquants en cavale, ils sont réduits à vivre d'expédients plus ou moins lucratifs : laveurs de parebrise, cireurs de chaussures, vendeurs de cigarettes à l'unité, dealers, prostitué(e)s à un dollar, mendiants ou mini-gangsters. Par-delà toutes ces tentatives, souvent désespérées, de socialisation et de survie, leur attention s'est fixée sur le Staff Benda Bilili, singulier rassemblement d'adultes musiciens handicapés (polios dans leur majorité) et de jeunes volontaires sans qualification mais disposés à s'investir dans un projet social et artistique.

2 Fréquentant le Rond-Point Sonas, les trottoirs du centre-ville, le zoo à l'abandon de Kinshasa, ou la boutique fourre-tout de Ricky l'un des leaders, les deux cinéastes découvrent avec stupéfaction un véritable orchestre issu de la rue et entraîné par les figures tutélaires de Coco Yakala, chanteur et guitariste, Ricky, Roger, Théo, véritables forces de la nature au charisme époustouflant, produisant des sons inouïs sur leurs instruments précaires, s'accompagnant "de voix de crooners au velours usé".

3 Pour favoriser les contacts et rester en phase avec le groupe, ils apprennent les rudiments de la langue "lingala", mais surtout ils apportent quelques subsides aux plus démunis pour éviter le découragement ou l'abandon en période de catastrophe (un incendie détruit le local qui facilitait l'hébergement, l'entrepôt de matériel, les répétitions). 
4 L'essentiel est que le travail avance. L'enregistrement progresse et surmonte les difficultés techniques. La consécration, sous forme de tournée en Europe, se profile.

5 Le film naît de cette rencontre et, au-delà des apparences, relate une surprenante success story.

6 Une poignée d'adultes handicapés, du haut de leurs fauteuils roulants customisés, se lancent à "fond la caisse" dans l'aventure multiple. Il s'agit d'abord de rompre avec le mauvais sort, avec les paralysies de l'indifférence ou de l'hostilité du monde environnant. Le vecteur de ce sursaut sera musical et puisera aux sources des rythmes populaires avec nombre d'instruments ingénieusement bricolés. Les galères du quotidien, les espoirs aussi, inspireront les paroles. L'intégration de quelques gosses d'exception, mi-énergumènes, mi-phénomènes apportera la touche finale et roule le Staff Benda Bilili, des ornières de Kinshasa et de son zoo aux fauves faméliques, aux hôtels pleins d'étoiles et de clients repus des pays nordiques! En apothéose, les foules extasiées de Copenhague ou de Belfort (les Eurockéennes)... Le reste du monde suivra. Une épopée roborative. 